\title{
Morphometry and number of spermatozoa in drone honeybees (Hymenoptera: Apidae) reared under different conditions
}

\author{
Adel M. MAZEED \\ Faculty of Agriculture, Department of Entomology, Cairo University, Egypt; e-mail: adelmazeed@hotmail.com
}

Key words. Hymenoptera, Apidae, drones, drone brood, morophometrical characters, number of spermatozoa

\begin{abstract}
The effects of three factors operating during pre-emergence development period on some characteristics of drones were studied. Weight of newly emerged drones, length of forewing, length of tibia, length of femur, length and width of basitarsus and number of spermatozoa in drones from colonies in which the workers had access to drone brood (A), the size of brood cells differed (B) or the colony had a queen or was queenless (C), were determined. For this purpose, 9 colonies were chosen at random from the test apiary and prepared so that each contained one empty Langstroth frame with six small sub-frames containing drone combs, three of which were used to test the effect of one level and the other three the other level of each factor. The results showed that, colony status had a greater effect on the parameters measured than either the size of the brood cells or whether the workers had access to sealed brood cells. Most of the parameters were significantly different in C, whereas only a few in B and non in A were significantly different. The distance between discriminant scores in each experiment enhanced the previous results, as it was highest in $\mathrm{C}$, followed by B and then A. Optimal drone characteristics may be recorded for colonies in which the queens were induced to lay unfertilized eggs in newly built drone combs, and then removed and the drone brood reared in a queen less colony.
\end{abstract}

\section{INTRODUCTION}

Although honeybee drones don't forage or participate in colony maintenance they contribute with the queens to the genotype of the female offspring, and it is of paramount importance for beekeepers that produce queens and those that buy queens, that an abundance of drones of a designated stock be present at the place and time when bees mate in order to ensure insemination by drones of a desired stock (Laidlaw \& Page, 1998).

Drones are produced from unfertilized eggs that are laid in drone cells by queens or in worker cells by workers. After egg laying the workers care for the immature stages by supplying them with food and maintaining the temperature. Both genetic factors and environmental conditions during their development and after emergence affect the quality of the resultant drones. Africanized drones weigh less and have fewer spermatozoa than European drones (Rinderer et al., 1985). Ruttner (1966) mentions that drones that are poorly fed during their development are poor at mating. In addition, the maturation of drones is accelerated when the temperature in the brood nest is $35^{\circ} \mathrm{C}$ (Mindt, 1962). Ruttner (1976) mentions that the queen should be removed as the colony will take better care of the drones if the colony is queenless. Woyke (1995) reports that by changing rearing conditions, larger worker bees can be reared in comb cells of the same size.

The comb cell size determines the body size of emerging drones. Drones emerging from worker cells weigh less and are smaller than those emerging from drone cells (Berg, 1991; Schluens et al., 2003; Gencer \& Firati, 2005). Berg et al. (1997) report that small drones reared in worker cells are at a reproductive disadvantage compared to large drones reared in drone cells. In comb cells of the same type, the accumulation of cocoons and larval faeces in old combs diminishes the space available for rearing larvae (Free, 1977).

In this study, the effect of the age of drone combs, access of workers to sealed drone brood and colony status, on some characteristics of honey bees were investigated.

\section{MATERIAL AND METHODS}

\section{Experiment set up}

This study was carried out in the spring and summer of 2008 and 2009 at the beekeeping section, Faculty of Agriculture, Cairo University.

Nine hybrid colonies were selected for rearing drones. The rearing of drones was induced by putting an empty Langstroth frame in each colony, in which most of the drone cells were subsequently built. For the different treatments, six small frames were fixed in each Langstroth frame placed in the brood nest of each drone rearing colony (Fig. 1). The colonies were supplied continuously with diluted sugar syrup to stimulate, accelerate and enhance comb building. After drone eggs were laid, the small combs in the small frames were treated differently as described below.

\section{Experiment 1}

Three experimental colonies were chosen for studying the effect of worker access to sealed brood. During the period of 24 $\mathrm{h}$ after the cells with drone brood were sealed, two or three small combs from each of the three experimental colonies were transported to an incubator and kept at $32^{\circ} \mathrm{C}$ and relative humidity $60-80 \%$ until the drones emerged. The other small combs containing drone brood were left in the rearing colony until 2 days before drone emergence and then placed in the incubator. 


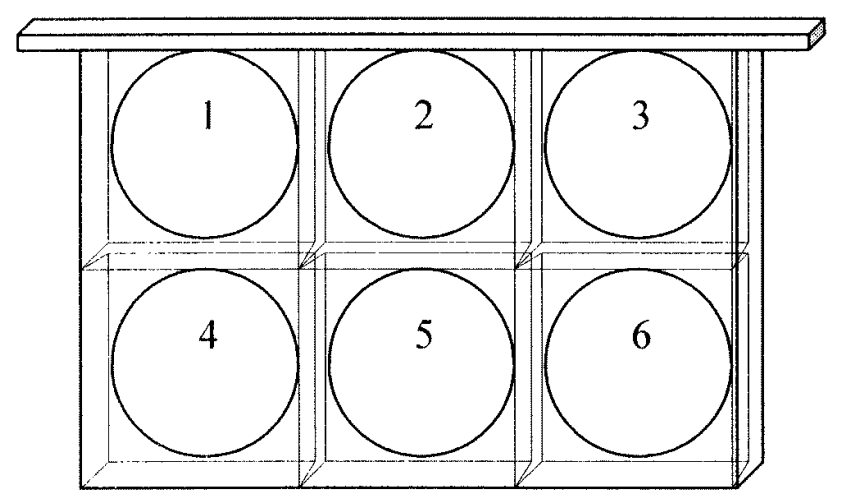

Fig. 1. Experimental frames were divided into 6 parts.

\section{Experiment 2}

In other three experimental colonies the effect of comb age on different characteristics of drones were determined by cutting three dark small drone combs (more than one year old) from old drone combs and fixing them in three of the six small frames in each rearing colony. The other small drone combs in the remaining frames were left to the bees to build.

Single measurements of the distance spanned by 10 old drone cells were carried out so that the comb cells could be classified according to size (Rinderer et al., 1986; Berry, 2010). The distance spanned by 10 drone cells ranged from 6.3 to $7 \mathrm{~cm}$, with an average of $6.60 \pm 0.2$ in newly built combs and from 5.7 to 6.7 , with an average of $6.34 \pm 0.34$ in old combs.

The drone eggs that were laid in these combs were left to develop in the rearing colony until 2 days before drone emergence when they were transferred to the incubator.

\section{Experiment 3}

The remaining three colonies were prepared for studying the effect of the presence or absence of a queen on drone characteristics. For this purpose, each colony was divided into two equal parts after the drone eggs were laid, one part contained the old queen and the other was queenless. Each part of the divided colony had three of the small drone combs containing drones eggs, which were left in the colony until 2 days before the drones were due to emerge, when they were transferred to an incubator.

Colonies were fed sucrose syrup continuously every 2 days to increase brood rearing and create swarming conditions.

\section{Measuring of characters}

Several different characteristics of a sample of 10 newly emerged drones ( $24 \mathrm{~h}$ old) were measured. Firstly, the drones were weighed on an electronic balance to the nearest $0.1 \mathrm{mg}$. The drones that were weighed were used also for studying other characters.

The right forewing and hind leg were removed from each drone using fine forceps and preserved in $70 \%$ ethanol for morphological examination. The lengths of the fore wing, femur, tibia, tarsus and width of the basitarsus of the hind leg were measured using a dissecting binocular-microscope fitted with a micrometer lens (Fig. 2). The drones were dissected in $0.9 \%$ saline solution after pinning them onto a wax plate.

With the aid a fine needle and forceps semen was forced from right testis into a small Petri dish containing $1 \mathrm{ml}$ of saline solution $(0.9 \%)$ (Mackensen \& Tucker, 1970). Tap water was added to make a total volume of $10 \mathrm{ml}$. The number of spermatozoa was estimated by counting the number in a known volume, 1 $\mathrm{mm}^{3}$, of suspension, which is equivalent to five replicate fields

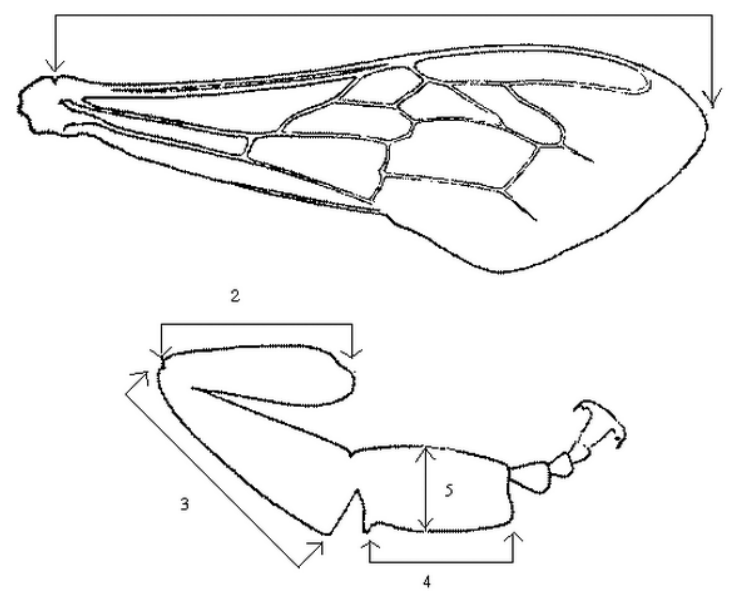

Fig. 2. Distances measured on the forewing and hind leg: 1length of forewing; 2 - length of femur; 3 - length of tibia; 4 length of basitarsus; 5 - width of basitarsus.

of a Thoma counting chamber, and the results expressed in terms of the number present in $10 \mathrm{ml}$ (Schluens et al., 2003).

\section{Statistical analysis}

Welch's t-test was used to compare pair means (Sokal \& Rohlf, 1995). In addition, a discriminant analysis of each pair of treatments was used to determine the Eucledian distance between each pair. The data were analyzed using the Almostatistic-system (Holm, 2010).

\section{RESULTS}

\section{Worker access to sealed drone brood}

In spite of the tendency of the parameter values to be higher in drones incubated naturally as part of the brood of bee colonies rather than artificially incubated, the difference was not significant (Table 1).

\section{The size of the brood cells}

All the parameters of the drones that originated from brood reared in new large comb cells differed from those of drones that originated from old small comb cells. The differences between the two groups were, however, significant only in weight and length of tibia (Table 2).

\section{Presence or absence of queens}

Drones reared in colonies without queens were bigger in terms of all the parameters measured. As shown in

TABLE 1. Mean values ( \pm Standard deviation) of weight $(\mathrm{mg})$, the different morphometrical characters $(\mathrm{mm})$ and number of spermatozoa (million) in drones that emerged from sealed brood in colonies or were reared in an incubator.

\begin{tabular}{lccc}
\hline & Incubator & Colony & T-Welch \\
\hline Weight & $226.4 \pm 22.87$ & $234.8 \pm 20.61$ & $1.43, \mathrm{~ns}$ \\
Length of wing & $11.84 \pm 0.26$ & $12.02 \pm 0.26$ & $1.95, \mathrm{~ns}$ \\
Length of tibia & $3.80 \pm 0.12$ & $3.83 \pm 0.14$ & $0.64, \mathrm{~ns}$ \\
Length of femur & $3.24 \pm 0.09$ & $3.28 \pm 0.1$ & $1.12, \mathrm{~ns}$ \\
Length of basitarsus & $2.52 \pm 0.06$ & $2.58 \pm 0.17$ & $1.55, \mathrm{~ns}$ \\
Width of basitarsus & $1.34 \pm 0.13$ & $1.37 \pm 0.07$ & $0.82, \mathrm{~ns}$ \\
Number of sperms & $3.02 \pm 1.10$ & $3.14 \pm 0.89$ & $0.47, \mathrm{~ns}$ \\
\hline
\end{tabular}


TABLE 2. Mean values ( \pm Standard deviation) of the weight $(\mathrm{mg})$, different morphometrical characters $(\mathrm{mm})$ and the number of spermatozoa (million) in drones reared in new and old drone combs.

\begin{tabular}{lccc}
\hline Characters & New cells & Old cells & T-Welch \\
\hline Weight & $200.7 \pm 26.31$ & $181.7 \pm 24.25$ & $2.62, \mathrm{p}<0.05$ \\
Length of wing & $11.87 \pm 0.27$ & $11.73 \pm 0.26$ & $1.86 \mathrm{~ns}$ \\
Length of tibia & $4.02 \pm 0.09$ & $3.95 \pm 0.1$ & $2.51, \mathrm{p}<0.05$ \\
Length of femur & $3.33 \pm 0.11$ & $3.3 \pm 0.08$ & $1.27, \mathrm{~ns}$ \\
Length of basitarsus & $2.91 \pm 0.07$ & $2.87 \pm 0.07$ & $1.72, \mathrm{~ns}$ \\
Width of basitarsus & $1.27 \pm 0.06$ & $1.28 \pm 0.08$ & $0.78, \mathrm{~ns}$ \\
Number of sperms & $4.05 \pm 1.32$ & $3.87 \pm 0.74$ & $0.64, \mathrm{~ns}$ \\
\hline
\end{tabular}

Table 3, the differences were highly significant for all the parameters except the width of the basitarsus.

\section{Discriminant analysis}

In the discriminant analysis, group centroids were calculated to maximize the difference between each pair of treatments in the three experiments. Fig. 3 shows the Euclidian distances between centroids representing the two levels of each factor. There was a greater (2.68 units) and statistically significant $(\mathrm{p}<0.01)$ difference between the characteristics of drones from queenless colonies and those with queens followed by that of the drones reared in different ages of comb $(1.42$ units, $\mathrm{p}<0.05)$. The least difference was between drones that developed in a colony and in an incubator (1.19 units, $\mathrm{p}>0.05)$.

\section{DISCUSSION}

The results indicate that the absence of a queen had greater effect on the characters measured than the age of drone combs or the contact between drones in sealed brood cells and worker bees. That is, orphan colonies take better care of drones than colonies with queens, as previously reported by Ruttner (1976). The amount of food given to drone larvae may, therefore, vary depending on the status of the colony, that is, drone larvae are not provided with a fixed amount of food for growth. Worker larvae in queenless colonies receive more food than those in colonies with queens (Woyke, 1999). This is not a result of different numbers of workers per larva in colonies with queens and those lacking queens, but of the absence of queen substance, which probably results in changes in feeding behaviour shortly after removing the

TABLE 3. Mean values ( \pm Standard deviation) of the weight $(\mathrm{mg})$, different morphometrical characters $(\mathrm{mm})$ and number of spermatozoa (million) in drones reared in colonies with and without queens.

\begin{tabular}{lccc}
\hline Characters & Queen present & Queen absent & T-Welch \\
\hline Weight & $210.6 \pm 26.51$ & $225.8 \pm 16.71$ & $2.56 \mathrm{P}<0.05$ \\
Length of wing & $11.71 \pm 0.22$ & $12.95 \pm 0.23$ & $3.82 \mathrm{P}<0.01$ \\
Length of tibia & $3.85 \pm 0.11$ & $3.95 \pm 0.10$ & $3.28, \mathrm{P}<0.01$ \\
Length of femur & $3.18 \pm 0.1$ & $3.3 \pm 0.07$ & $4.71, \mathrm{P}<0.01$ \\
Length of basitarsus & $2.83 \pm 0.08$ & $2.91 \pm 0.09$ & $3.24, \mathrm{P}<0.01$ \\
Width of basitarsus & $1.32 \pm 0.07$ & $1.36 \pm 0.09$ & $1.89 \mathrm{~ns}$ \\
Number of sperms & $3.690 \pm 0.61$ & $4.46 \pm 1.0$ & $3.43, \mathrm{P}<0.01$ \\
\hline
\end{tabular}

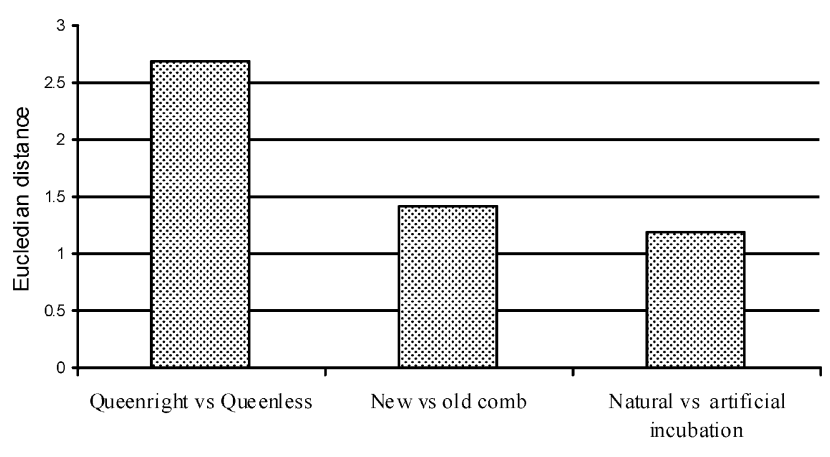

Fig. 3. Eucledian distance between discriminant scores in the three experiments.

queen that result in an increase in the feeding rate (Kuabara, 1947). The results presented indicate that not only do workers change their feeding behavior towards worker larvae but also towards drone larvae. In addition, the increase in the feeding rate affects the characteristics of the drones. This accords with results of Woyke (1995), who states that worker bees reared in queen less colonies are significantly larger than those reared in colonies with queens.

Artificial incubation of drone brood did not significantly affect the characters measured. The constant temperature experienced in the incubator seems to have been as effective as the fluctuations in temperature that occur in bee colonies. In addition, the absence of the direct contact between nursery bees and sealed drone brood did not negatively affect the characteristics of drones. According to Mazeed \& Mohanny (2007), direct contact between sealed queen cells and worker bees during the first 4 days after sealing significantly affects the number of the ovarioles but has no effect on the morphological characters of the resultant queens.

In this study, direct contact did not significantly affect the characteristics of drones. So, bee breeders could benefit from transferring sealed drone brood from rearing colonies to an incubator in order to obtain more drone brood and shorten the time for producing drones, since it takes 15 days for drones to complete their development and emerge from sealed brood cells.

Concerning the size of comb cells and whether it affects the external morphology of the resultant drones (Gencer $\&$ Firati, 2005) it did not significantly affect the external parameters measured in this study. There might be an influence of comb cell size if the cells used exceed the limits normally recorded in colonies. Gencer \& Firati (2005) reared drones in drone and worker cells. In this study, the average diameter of new drone comb cells was $6.6 \mathrm{~mm}$, whereas that of old drone cells was $6.34 \mathrm{~mm}$.

Although both the size of comb cells and access of workers to sealed drone brood were not so important in determining the characteristics of the resultant drones, they may have an additive effect when all other factors are optimal for development. Therefore, it is recommended that rearing colonies are provided with new drone combs and the drones be allowed to complete their 
development in queenless colonies as the resultant drones are larger and contain more spermatozoa.

\section{REFERENCES}

BERG S. 1991: Investigation on the rates of large and small drones at drone congregation area. Apidologie 22: 437-438.

Berg S., Koeniger G. \& Fuchs S. 1997: Body size and reproductive success of drones (Apis mellifera L). Apidologie 28: 449-460.

Berry J. 2010: Klein, aber nicht fein. Dt. Bienen J. 18(1): 18.

FREE J. 1977: The Social Organization of Honeybees. Edward Arnold, London, $68 \mathrm{pp}$.

Gencer H.V. \& Firati C. 2005: Reproductive and morphological comparisons of drones reared in queenright and laying worker colonies. J. Apic. Res. 44: 163-167.

Holm K. 2010: Almo-Statistik-System. Univ. Linz, Austria.

Kuwabara M. 1947: Ueber die Regulationin weiselosen Volke der Honigbiene (Apis mellifeca), besonders die Bestimmung des neuen Weisels. J. Fac. Sci. Hokkaido Univ. (VI, Zool.) 9: 359-381.

Laidlaw H.H. \& Page R.E. 1998: Queen Rearing and Bee Breeding. Wicwas Press, Cheshire, CT, 224 pp.

MACKensen O. \& TUCKeR K. 1970: Instrumental Insemination of Queen Bees. Agric. Handbook, No. 390, USDA, Washington, $28 \mathrm{pp}$.

Mazeed A.M. \& Mohanny K.M. 2007: Effect of access of worker bees to sealed queen cells on some morphological characters of the produced queens. J. Agric. Sci. Mansoura Univ. 32: 5635-5639.

MindT B. 1962: Untersuchung ueber das Leben der Drohnen, insbesondere Ernaehrung und Geschlechtsreife. Z. Bienenforsch. 6: 9-33.

Rinderer T., Collins A.M. \& Pasante D. 1985: A comparison of Africanized and European drones: weights, mucus gland, seminal vesicle weights, and count of spermatozoa. Apidologie 16: 407-412.

Rinderer T.E., Sylvester H.A., Brown M.A., Vill J.D., Pesante D. \& Collins A.M. 1986: Field and simplified techniques for identifying Africanized and European honey bees. Apidologie 17: 33-48.

RUtTNER F. 1966: The life and flight activity of drones. Bee World 47: 93-100.

RUTTNER F. 1976: The Instrumental Insemination of Queen Bee. Apimondia, Bucharest, $123 \mathrm{pp}$.

Schluens H., Schluens E.A., Van Praagh J. \& Morit R. 2003: Sperm numbers in drone honeybees (Apis mellifera) depend on body size. Apidologie 34: 577-584.

Sokal R.R. \& RohlF F.J. 1995: Biometry. W.H. Freeman, New York, $887 \mathrm{pp}$.

Woyke J. 1995: Rearing larger honeybee workers. In: Proceedings of the XXXIV. Int. Apicultural Congress, Lausanne, Switzerland. Apimondia, Bucharest, pp. 124-127.

Woyke J. 1999: Increased food supply for all larvae after dequeening honeybee colonies. J. Apic. Res. 38: 117-123.

Received February 8, 2011; revised and accepted April 5, 2011 